\title{
THE GIANT BASS OF JAPAN.
}

\section{By David Starr Jordan and John Otterbein SNyder, Of Stanford University, California.}

On the coasts of Japan are found two species of bass. like fishes, each reaching a huge size and comparable to the immense fishes known as jew-fishes on the coast of the United States. These species are the Ishinagi (stone-bass) or O'uwo (giant fish), Stereolepis ischinagi, (=Megaperca ischinagi Hilgendorf), and the Aburabodzu (fat-priest) (Erilepis zonifer Lockington=Ebisus sagamius Jordan and Snyder). The first species belongs to the family Serranidx, the other to the family Anoplopomatidæ, the two being not at all related. The accompanying plates are by Mr. William S. Atkinson.

\section{STEREOLYPIS ISCHINAGI (Hilgendorf).}

Megaperca ischinagi Hilgendorf, Sitz, Naturf, Freunde, Berlin, 1878, p. 156 (Tokyo).-Steindachner and Doderlein, Fische Japans, I, 1883, p. 228, pl. iII, fig. 3 (Tokyo).-Jordan and Snyder, Check-List Fishes Japan, 1900 , p. 73 (Yokohama).-Jordan and Snyder, Proc. U.S. Nat. Mus., XXIII, 1900 (July 2, 1901), p. 354 (Tokyo).

Head, $2 \frac{9}{10}$ in length to base of caudal; depth, $2 \frac{3}{4}$; depth of caudal peduncle, $8 \frac{1}{2}$; snout, $3 \frac{2}{5}$ in head; maxillary, $2 \frac{1}{4}$; eye, 5 ; width of interorbital space, 4; D. XII, 11; A. III, 7; scales, 14-87-31.

Interorbital space flat; lower jaw projecting; preorbital and suborbital with strong ridges, the suborbital ridges uniting to form a single crest, which extends upward behind the eye; lips thick; maxillary extending to a point below posterior edge of orbit, its upper edge covered anteriorly by the preorbital; supplemental maxillary distinct, its lower edge with a pronounced ridge. Teeth in broad villiform bands on jaws, vomer, palatines, and upper and lower pharyngeals; tongue smooth. Large pseudobranchiæ present; gillrakers, $3+8$, large and strong. Opercle with 2 spines, the upper short and broad, the lower longer and more pointed; preopercle strongly serrate; subopercle with a few serrations; edge of interopercle rough; throat, snout and top of head naked; occipital and parietals with a few strong radiating ridges, which show through the naked skin; cheeks and opercles scaly; scales 
of head and body cycloid, growing slightly ctenoid posteriorly; each scale with a vertical, tuberculate ridge, imparting a characteristic roughness to the covering of the body; fins with minute scales; lateral line following the contour of back; first dorsal spine very short, almost entirely concealed; the fifth ray longest, $1_{5}^{4}$ in head; membrane of spinous dorsal deeply incised between spines, the attached portion of the membrane extending half way up anterior edge of spine; longest dorsal ray, 245 in head; edge of fin, rounded; origin of anal below base of third dorsal ray; the spines strong and prominent, the second, $4 \frac{1}{2}$ in head; margin of fin rather pointed in outline; pectoral unsymmetrical, upper rays longest, $2 \frac{1}{3}$ in head; ventral, $1 \frac{3}{5}$; caudal, $6 \frac{1}{2}$, lunate.

Body olivaceous, with 6 broad lateral dusky stripes; the first extending along base of dorsal, the second following lateral line to caudal peduncle where it joins the third, the fourth passing from

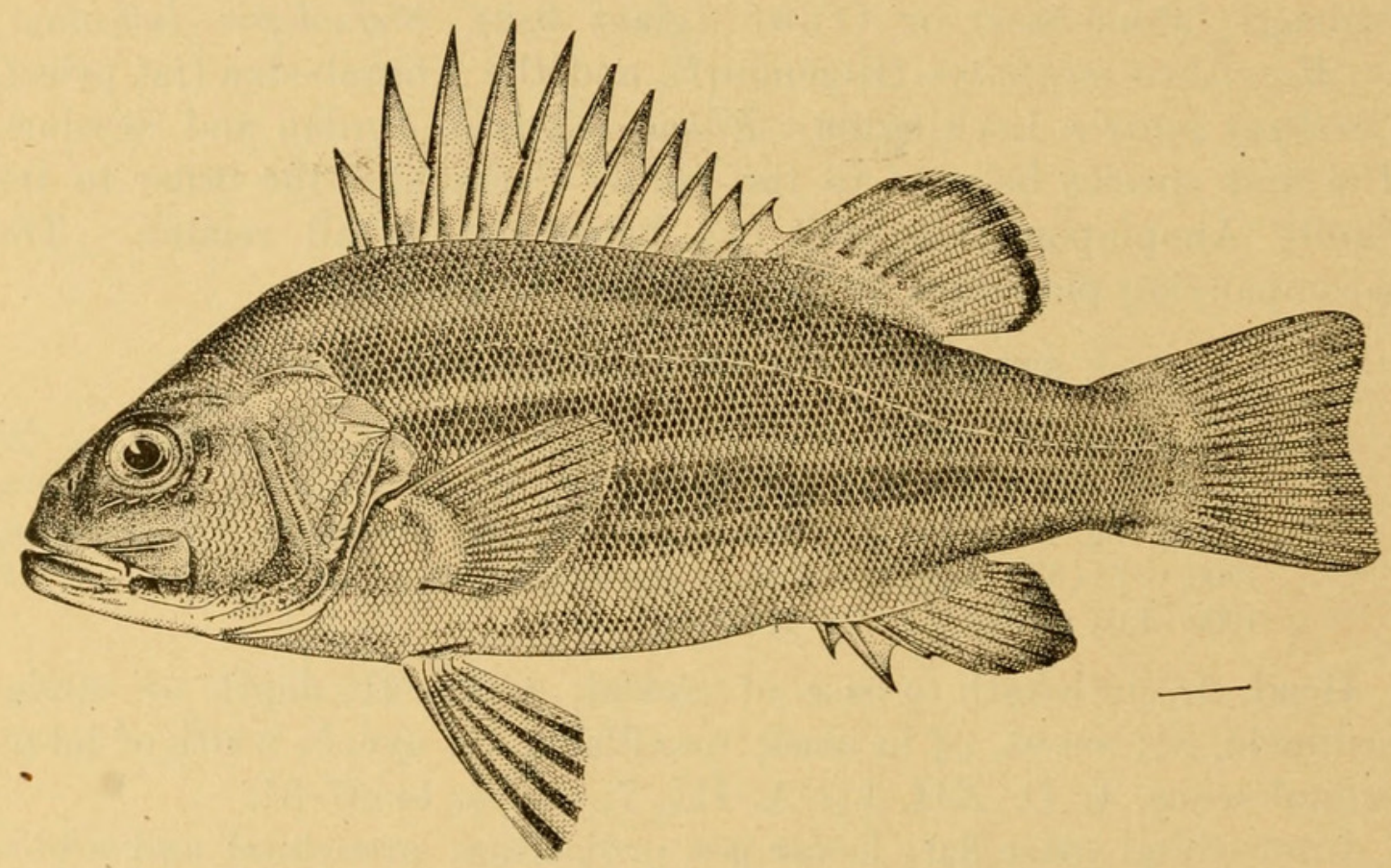

Fig. 1.-STEREOLYPIS ISCHINAGI.

base of pectoral to caudal, the fifth and sixth rather indistinct, merging near base of anal; head dusky above; soft dorsal, anal and pectorals strongly edged with dusky, the soft dorsal narrowly tipped with whitish.

Described from a specimen 14 inches long taken at Hakodate by the U. S. Fish Commission Steamer Albatross.

In our explorations of Japan we saw specimens of the Ishinagi at Hakodate, Tokyo, Yokohama, and Misaki. The largest of these was about 6 feet in length. The species is apparently more common in northern Japan than southward, the center of abundance being about Hakodate and the Straits of Tsugaru.

This species is well separated from Stereolepis gigas Ayres, of the coast of California, by the larger scales, and especially by the form of 
its spinous dorsal fin, the spines in Stereolepis gigas being very much lower. The nominal genus Megaperca, however, differs but slightly from Stereolepis, the only tangible character resting in the marked elevation of the dorsal spines, the first dorsal being low in Stereolepis. The scales in Stereolepis are a shade thicker and rougher, but the difference is not one of importance.

\section{ERILEPIS ZONIFER (Lockington).}

\section{ABURABODZU.}

Myriolepis zonifer Lockington, Proc. U. S. Nat. Mus., 1880, p. 248 (Monterey, California).-Jordax and Gilbert, Synopsis, Fish, North America, 1883, p. 649 (same specimen).

Erilepis zonifer Gill, Science, Jan. 6, 1894, p. 54 (generic name a substitute for Myriolepis preoceupied by Myriolepis Egerton, a genus of fossil fishes).Jordan and Evermann, Fish, North and Mid. Amer., II, 1898, p. 1863, Monterey Bay.-Sмiтh, MS., 1905 (specimen from Kochi, Japan).

Ebisus sagamius Jordan and Snyder, Journ. College Science, Imperial Univ.

Tokyo, XV, 1901, p. 508, pl. xv, figs. 3, 4, (Misaki, on Sagami Bay, Japan).

Erilepis zonifer was first known from a specimen a foot long, taken in Monterey Bay in 1879 by Mr. William Neale Lockington, this

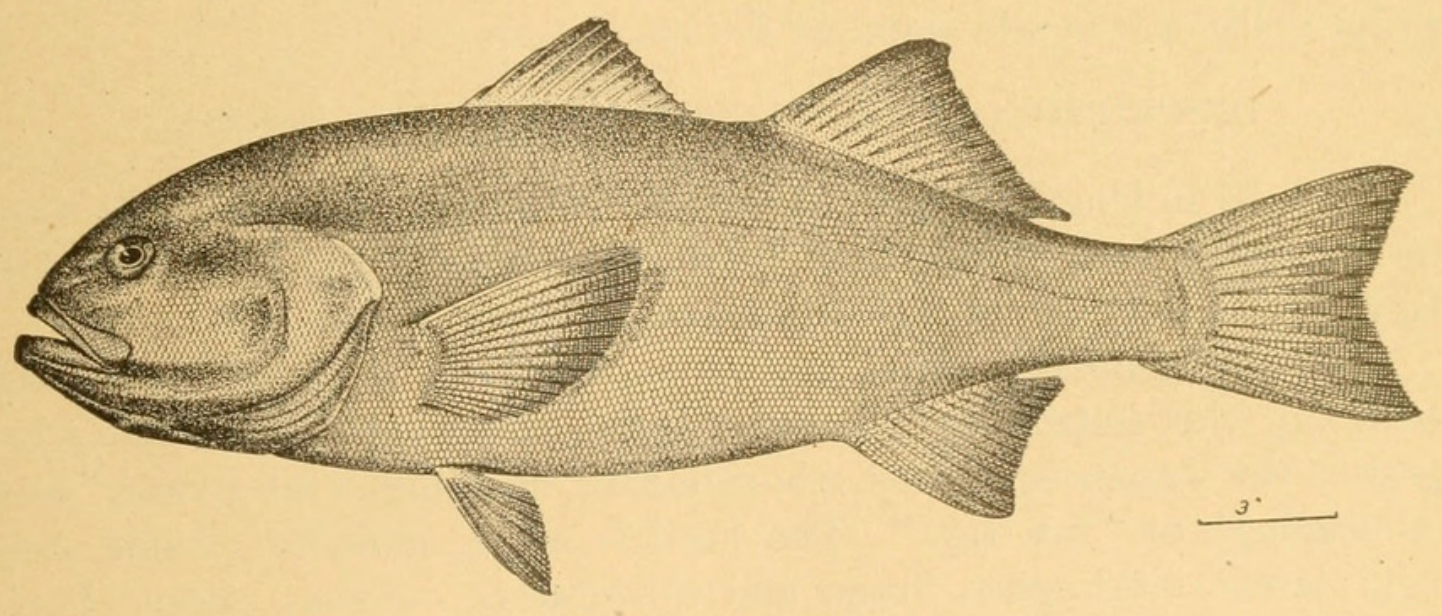

Fig. 2.-ERILEPIS ZONIFER.

specimen being placed in the Caỉifornia Academy of Sciences. No more specimens of this genus were known until the present writers found in the Imperial Museum at Tokyo a very large example, eviscerated and stuffed. In this specimen the union of the gill-membranes to the isthmus did not appear, and the existence of the suborbital stay beneath the skin of the cheek was not suspected. The fish was taken as the representative of a very aberrant new genus of Serranidx, and it was described under the name Ebisus sagamius.

For the information as to the identity of Ebisus with Erilepis we are indebted to Dr. Hugh M. Smith, who found a very young example, about 4 inches long, at Kochi, in the island of Shikoku, in Japan. This specimen was identified by Doctors Gill and Smith as the young of Erilepis zonifer, and on this suggestion we have reexamined our speci- 
men of Ebisus sagamius. We find it to be an Erilepis, and we can not separate it from Erilepis anifer.

We have now before us a large example in alcohol of the Aburabodzu, sent to us, together with measurements and photographs, by Mr. T. Matano, president-general of the Imperial Museum of Japan. From this specimen we are enabled to give a more exact description of the species, and to correct some errors in the account of Ebisus sagamius. Our specimen having been eviscerated, the characters of the tongue, gill-arches, and pyloric cæca can not be given. The anal fin is apparently without spines, but three very small ones appear on dissection in the thick oily skin. The top of the head is covered with fine, embedded scales. Our specimen differs from the account of the Californian specimen called Erilepis sonifer in the color, which no doubt changes with age, and in the number of dorsal spines. In our specimen the two dorsal fins are separated, and the fin-rays are D. XII-16. In Lockington's example we counted D. XIV-I, 15. This difference in the number of spines may be fallacious, as one or two may be concealed in the think skin of our adult specimen.

In any event it is certain that Ebisus is a synonym of Erilepis. The Japanese species is probably the original Erilepis annifer. If it should prove distinct it would stand as Erilepis sagamius.

\section{DESCRIPTION OF ERILEPIS ZONIFER FROM TOKYO.}

Head, $3 \frac{1}{2}$ in length; depth, $3{ }_{6}^{1}$; depth of caudal peduncle, $11 \frac{1}{2}$; eye, $6 \frac{2}{3}$ in head; snout, 3 ; width of interorbital space, $2 \frac{4}{5}$; length maxillary, $2 \frac{4}{5}$; D. XII-16; A. III-12; scales in lateral series, 122.

The body is notably short and stout, the skin thick and saturated with oil, this imparting a characteristic plumpness which has suggested the Japanese names Aburabodzu, meaning "fat priest," and Aburainagi, or "fat bass." The head is large; anterior profile convex; interorbital space broad and moderately convex; snout short; lower jaw projecting slightly; maxillary without supplemental bone, extending posteriorly to a point below middle of orbit; width of narrowest part of preorbital equal to vertical diameter of eye; nostrils, two on each side; anterior nostril circular, with an elevated rim, the posterior part of which rises in an angular prominence; posterior nostril oblong; branchiostegals 7 , their membranes scaly; teeth small, curved, in broad bands on jaws and on anterior ends of palatines and vomer; cheek with a long strong suborbital stay hidden under the thick skin; pseudobranchiæ present; gill-membranes rather narrowly united to the isthmus; head without spines or serrations, completely scaled except on lips; scales small, ctenoid, well embedded; those on upper anterior part of head, snout, and chin minute; rays and spines of fins generally with scales; posterior dorsal spines smooth; interradial membranes scaly, especially on the caudal; lateral line complete to 
base of caudal fin, following in curvature the dorsal contour of body; origin of spinous dorsal a little anterior to that of ventral; first dorsal spine short, almost concealed; third spine longest, $2 \frac{7}{5}$ in head; space between spinous and soft dorsal about equal to vertical diameter of eye; height of longest (third or fourth) dorsal ray, $2 \frac{2}{5}$ in head; origin of anal below fifth dorsal ray; spines of anal inconspicuous, partly concealed in fatty tissue and closely apposed to the first ray; the anterior one minute and easily overlooked; longest (first) ray $2 \frac{1}{4}$ in head; upper rays of pectoral longest, $1 \frac{1}{2}$ in head; ventral, $2 \frac{1}{5}$; posterior edge of caudal lunate, $1 \frac{3}{5}$ in head. Color in spirits, plain brown, the fins edged or tipped with dusky. Length, 35 inches. Tokyo, Japan.

The specimen probably came from the fisheries of Misaki. Although so rare in collections the species is well known to the fishermen. According to Kuma Aoki, master fisherman at Misaki, the species reaches a weight of 200 pounds. The type of Ebisus sagamins was 57 inches long (1.40 meters). 


\section{$2 \mathrm{BHL}$ Biodiversity Heritage Library}

Jordan, David Starr and Snyder, John Otterbein. 1906. "The giant bass of Japan." Proceedings of the United States National Museum 30(1476), 841-845. https://doi.org/10.5479/si.00963801.30-1476.841.

View This Item Online: https://www.biodiversitylibrary.org/item/53722

DOI: https://doi.org/10.5479/si.00963801.30-1476.841

Permalink: https://www.biodiversitylibrary.org/partpdf/53150

\section{Holding Institution}

Smithsonian Libraries

\section{Sponsored by}

Smithsonian

\section{Copyright \& Reuse}

Copyright Status: Public domain. The BHL considers that this work is no longer under copyright protection.

This document was created from content at the Biodiversity Heritage Library, the world's largest open access digital library for biodiversity literature and archives. Visit BHL at https://www.biodiversitylibrary.org. 